\title{
Acerentomon brozai sp.n. and similar species (Protura: Acerentomidae)
}

\author{
A. Szeptycki ${ }^{1}$, J. Shrubovych ${ }^{2}$ \\ ${ }^{1}$ Institute of Systematics and Evolution of Animals, Polish Academy of Sciences, ul. Slawkowska 17, \\ 31-016 Krakow,Poland.e-mail: szeptycki@isez.pan.krakow.pl \\ ${ }^{2}$ State Museum of Natural History, Ukrainian National Academy of Sciences, Teatral'na St. 18, \\ 79008 L'viv, Ukraine.e-mail: shrubovych@mail.ru
}

ABSTRACT: Acerentomon brozai sp.n. is described from Mt Carmel, Israel. A. dominiaki Szeptycki, 1977 and $A$. meridionale Nosek, 1960 are redescribed. The length of setae on pronotum (and their proportion), and the shape of meso- and metasternum are introduced as taxonomically important characters.

KEY WORDS: Protura, Acerentomon, new species, Israel.

\section{Новый вид Acerentomon brozai sp.n. и близкие виды (Protura: Acerentomidae)}

\author{
А. Шептицкий ${ }^{1}$, Ю.Е. Шрубович ${ }^{2}$ \\ ${ }^{1}$ Институт систематики и эволюиии животных ПАН, ул. Славковская, 17, 31-016 Краков, \\ Польша.e-mail: szeptycki@isez.pan.krakow.pl \\ ${ }^{2}$ Государственный природоведческий музей НАН Украины, ул. Театральная, 18, 79008 Львов, \\ Украина.e-mail: shrubovych@mail.ru
}

РЕЗЮМЕ: Описан новый вид Acerentomon brozai sp.n. с Израиля, горы Кармель. Переописаны два близких вида A. dominiaki Szeptycki, 1977 и A. meridionale Nosek, 1960. Длинна хет на переднегруди (и их пропорция), а также форма мезо- и метастернитов введены как таксономически важные характеристики.

КЛЮЧЕВЫЕ СЛОВА: Protura, Acerentomon, новые виды, Израиль.

\section{Introduction}

In the material of Protura from Israel, kindly sent us by prof. dr Meir Broza and Mrs Dina Poliakov, we have found the species of Acerentomon, previously determined by the senior author as A. meridionale Nosek, 1960 (Broza et al., 1966). Actually we have established that it is the new species - its description is given below. The new species is most similar to $A$. meridionale Nosek, 1960 and A. dominiaki

Printed in 2009
Szeptycki, 1977. Both the mentioned species were described (or redescribed) long time ago (Nosek, 1960, 1973; Szeptycki, 1977), so their redescription on the actual level is added.

All mentioned species belong to the " $m i$ crorhinus" group of Tuxen (1964). All are characterised by the lack of seta $x$ on urotergite VII and lack of posterior setae on urosternite VIII. The other important characters are: long setae Pla on nota, equal and smooth (with no basal dilation) sensilla of maxillary palp, sensillum of the labial palp dilated basally, lack of additional seta on head, very thick (but relatively short) and 
Table. Body chaetotaxy of Acerentomon brozai sp.n. Таблица. Хетотаксия тела Acerentomon brozai sp.n.

\begin{tabular}{|c|c|c|c|c|}
\hline & \multicolumn{2}{|l|}{ dorsal } & \multicolumn{2}{|c|}{ ventral } \\
\hline & setae & formula & setae & formula \\
\hline Th. I & 1,2 & 4 & $\begin{array}{c}\mathrm{A} 1,2, \mathrm{M} 1,2 \\
\mathrm{P} 1,2,3\end{array}$ & $\frac{4+4}{6}$ \\
\hline Th. II & $\begin{array}{c}\mathrm{M}, \mathrm{A} 2,3,4 \\
\mathrm{P} 1,1 \mathrm{a}, 2,2 \mathrm{a}, 3,3 \mathrm{a}, 4,5\end{array}$ & $\underline{8}$ & $\begin{array}{c}\text { Ac, } 2,3, \mathrm{M} \\
\mathrm{P} 1,3\end{array}$ & $\frac{5+2}{4}$ \\
\hline Th. III & $\begin{array}{c}\mathrm{M}, \mathrm{A} 2,3,4,5 \\
\mathrm{P} 1,1 \mathrm{a}, 2,2 \mathrm{a}, 3,3 \mathrm{a}, 4,5 \\
\end{array}$ & $\frac{10}{16}$ & $\begin{array}{c}\text { Ac, } 2,3,4, M \\
\text { P1, } 3\end{array}$ & $\frac{7+2}{4}$ \\
\hline Abd. I & $\begin{array}{c}\mathrm{A} 1,2,3 \\
\mathrm{P} 1,1 \mathrm{a}, 2,2 \mathrm{a}, 3,3 \mathrm{a}, 4 \\
\end{array}$ & $\frac{6}{14}$ & $\begin{array}{c}\mathrm{Ac}, 2 \\
\mathrm{P} 1,1 \mathrm{a} \\
\end{array}$ & $\frac{3}{4}$ \\
\hline Abd. II & $\begin{array}{c}\mathrm{A} 1,2,3,4,5 \\
\mathrm{P} 1,1 \mathrm{a}, 2,2 \mathrm{a}, 3,4,4 \mathrm{a}, 5 \\
\end{array}$ & $\frac{10}{16}$ & $\begin{array}{c}\text { Ac, (1), 2, } 3 \\
\text { Pc, 1a, 2 }\end{array}$ & $\frac{5(6)}{5}$ \\
\hline Abd. III & $\begin{array}{c}\mathrm{A} 1,2,3,4,5 \\
\mathrm{P} 1,1 \mathrm{a}, 2,2 \mathrm{a}, 3,4,4 \mathrm{a}, 5 \\
\end{array}$ & $\frac{10}{16}$ & $\begin{array}{c}\text { Ac, }(1), 2,3 \\
\text { Pc, 1a, } 2\end{array}$ & $\frac{(5) 6}{5}$ \\
\hline And. IV-VI & $\begin{array}{c}\mathrm{A} 1,2,3,4,5 \\
\mathrm{P} 1,1 \mathrm{a}, 2,2 \mathrm{a}, 3,4,4 \mathrm{a}, 5\end{array}$ & $\frac{10}{16}$ & $\begin{array}{l}\text { Ac, } 1,2,3 \\
\text { P1, 1a, 2, } 3\end{array}$ & $\frac{7}{8}$ \\
\hline Abd. VII & $\begin{array}{c}\mathrm{A} 1,2,3,4,5 \\
\mathrm{P} 1,1 \mathrm{a}, 2,2 \mathrm{a}, 3,4,4 \mathrm{a}, 5 \\
\end{array}$ & $\frac{10}{16}$ & $\begin{array}{c}\mathrm{Ac}, 2,3 \\
\mathrm{Pc}, 1,1 \mathrm{a}, 2,3 \\
\end{array}$ & $\frac{5}{9}$ \\
\hline Abd. VIII & $\begin{array}{c}\mathrm{A} 1,2,4,5 \\
\mathrm{Pc}, 1,1 \mathrm{a}, 2,2 \mathrm{a}, 3,3 \mathrm{a}, 5 \\
\end{array}$ & $\frac{8}{15}$ & 1,2 & 4 \\
\hline Abd. IX & $1,1 \mathrm{a}, 2,2 \mathrm{a}, 3,3 \mathrm{a}, 4$ & 14 & 1,2 & 4 \\
\hline Abd. X & $1,2,2 \mathrm{a}, 3,4$ & 10 & 1,2 & 4 \\
\hline Abd. XI & 3 & 2 & & 6 \\
\hline Telson & & 9 & & $\frac{0}{6}$ \\
\hline
\end{tabular}

parallel-sided foretarsal sensillum $b$, hind margin of urosternite VIII smooth, and conical, elongated and slender acrostyli. The body chaetotaxy is nearly identical in all the species (Table).

\section{Material and methods}

Material was collected in different regions of Israel by M. Broza and D. Poliakov during 1994-1997 years and in 2004. The Protura were placed into Mark-Andre 2 and Fore's solutions and identified. The type material of Acerentomon brozai sp.n. was investigated in collections of Institute of Systematics and Evolution of Animals, Polish Academy of Sciences, Krakow (ISEA PAS), and State Natural History Museum of Ukrainian National Academy of Sciences, L'viv (SNHMU). The materials of $A$. dominiaki Szeptycki, 1977 and $A$. meridionale Nosek, 1960 were investigated in collection of ISEA PAS.

\section{Results}

\section{Acerentomon brozai sp.n.}

Figs 1, 2.

Material examined. Holotype: \$: Israel, Mt. Carmel, Nahal Oren, north facing slope, pistachio-oak forest ( $P$ istacia palestina and Quercus calliprinos); in soil, 9.03. 1997; leg. M. Broza \& D. Poliakov.

Other materials. Together with the holotype: 2 우 (paratypes nr 1 and 2); Mt. Carmel, Givat Wolfson, burnt pine forest (Pinus halepensis), 15.12.1995: 1 (paratype nr 5), 1 preimago, 3 maturi juniores, 2 larvae II, 1 larva I; Mt. Carmel, Reches Etzba, burnt and unburnt pine forest, 22.11.1994 and 16.04.1995: 1 preimago, 1 maturus junior; Upper Gallilee, Amirim, planted pine forest, unburnt plot, in soil, 28.01.1995: $1 \sigma^{7}$ (paratype nr 3), 1 larva II; Mt Hermon, altitude $1600 \mathrm{~m}$, under Juniperus drupacea, in soil, 1.06.1997: 1 q (paratype nr 4); Judean Hills, Adulam, low trees, mainly Quercus calliprinos and Pistacia palaestina with dense shrubs of Phillyrea latifolia and Pistacia lentiscus on limestone, 4.04.2004: $1 \sigma^{7}$ (paratype nr 17.1), 2 maturi juniores; Sha'ar Hagai, on the way to Jerusalem, unburnt area, 15.04.1996: 1 maturus junior, 1 larva II.

Holotype and most of the material is preserved in the collection of the ISEA PAS, paratype nr 17.1 and 2 maturi juniors from Adulam in the SNHMU, paratype nr 5 and 

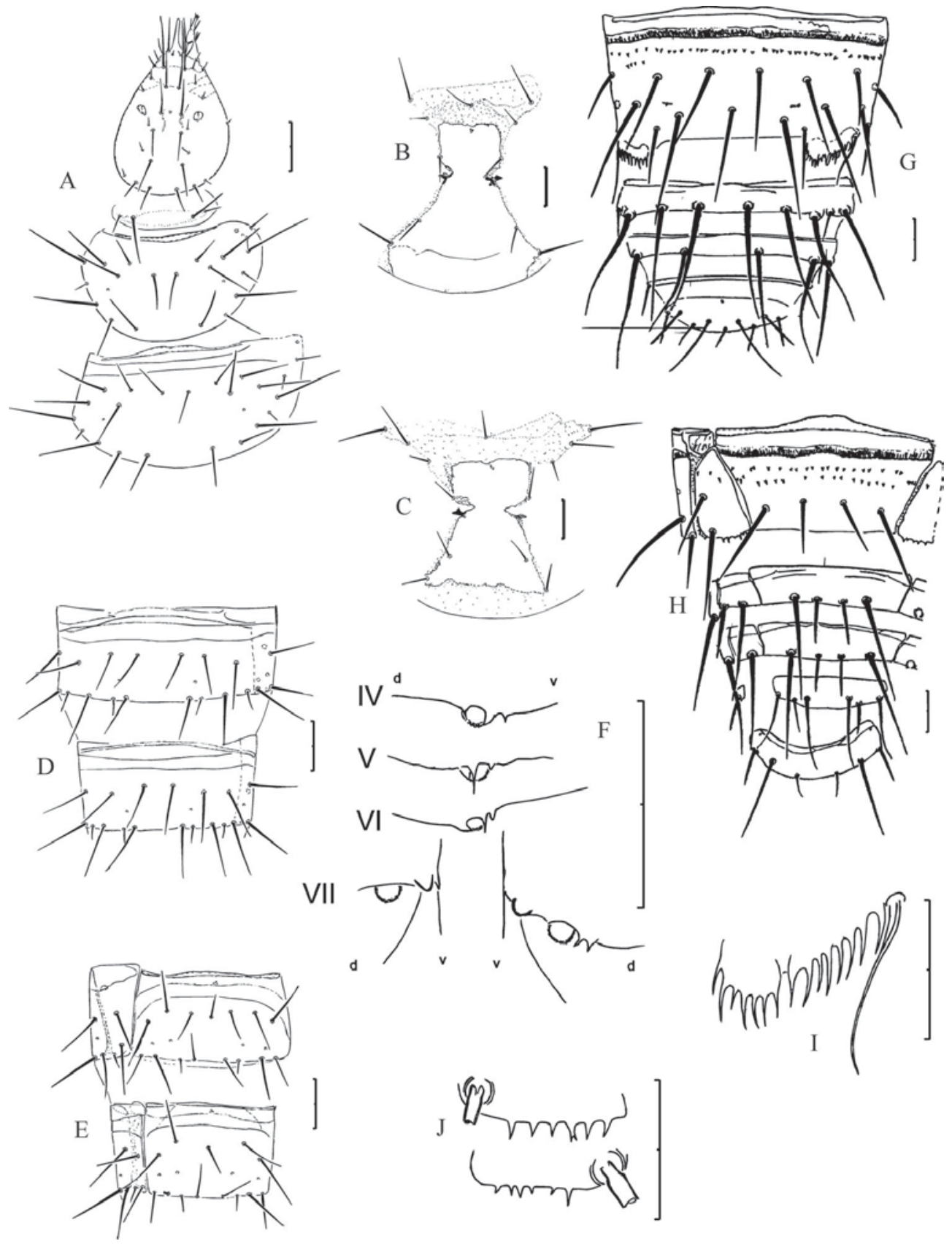

Fig. 1. Acerentomon brozai sp. n. (F, I, I - paratype Nr 1, others - holotype).

A - head and nota; B - mesosternum; C - metasternum; D - tergite VI and VII; E - sternite VI and VII; F laterotergal structures; G - tergite VIII - telson; H - sternite VIII; I - comb VIII; J - hind margin of laterotergite VIII. Scale bars: A, D, E $-50 \mu \mathrm{m}$, others $-20 \mu \mathrm{m}$.

Рис. 1. Acerentomon brozai sp.n. (F, I, I — паратип № 1; остальные - голотип).

А - голова, переднее- , средне- и заднегрудь; В - мезостернум; C - метастернум; D - тергиты VI и VII; E стерниты VI и VII; F - структуры латеральной части тергитов; G - тергиты VIII — тельсон; Н — стерниты VIII — тельсон; I — комб VIII; J — задний край латеротергита VIII. Масштаб: A, D, E — 50 мкм, остальные — 20 мкм. 


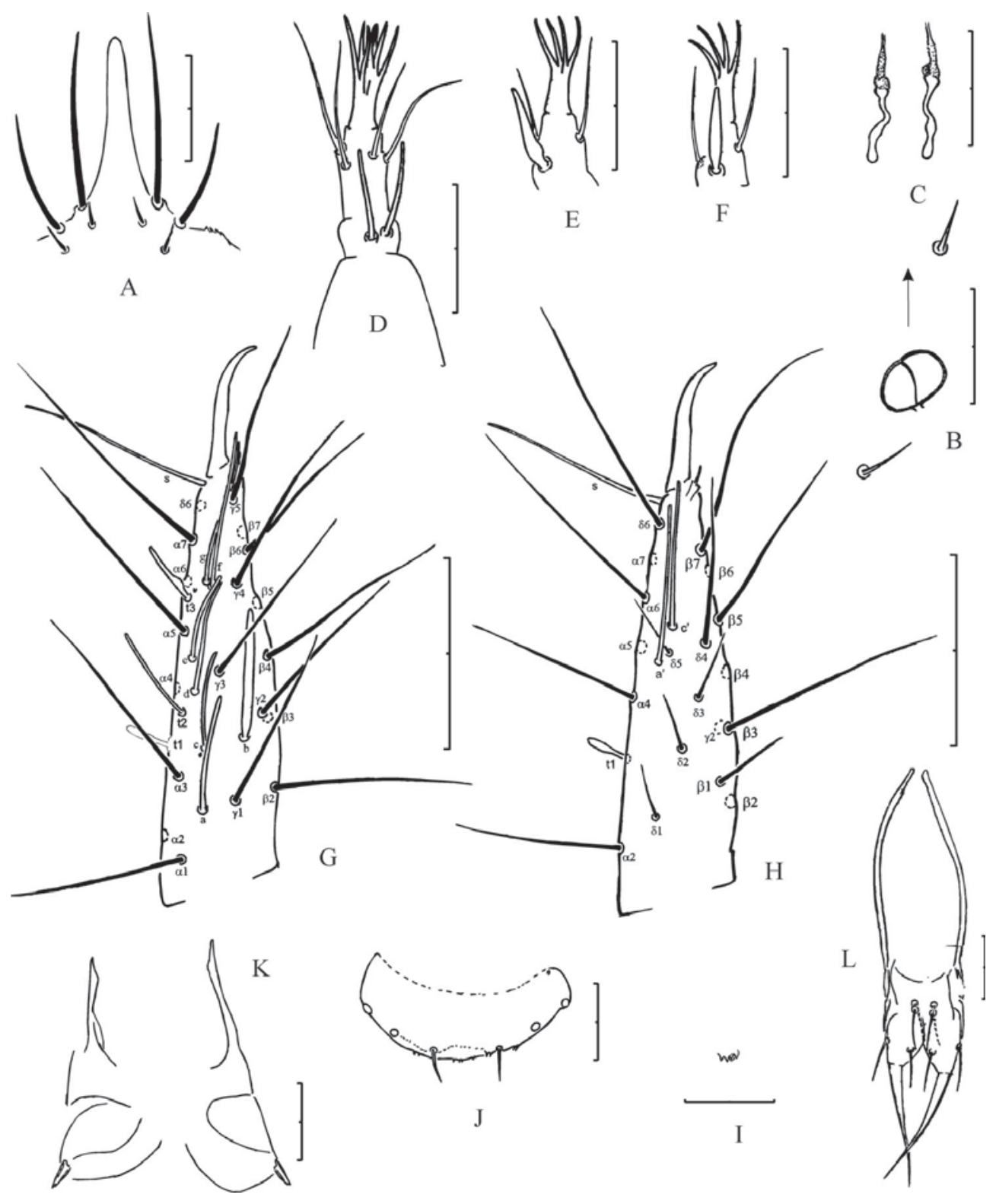

Fig. 2. Acerentomon brozai sp.n. (G, H - paratype $\mathrm{Nr} 1$; D-F — paratype $\mathrm{Nr} 4$; B, C - paratype $\mathrm{Nr} 5$; others - holotype).

A — rostrum; B - pseudoculus; C - maxillary gland; D - maxillary palp; E, F - labial palp; G — foretarsus, exterior view; $\mathrm{H}$ - foretarsus, interior view; I - pore $p s m$ and surrounding structures on urotergite VIII; J - ventral lobe of telson; K - female squama genitalis; L - penis. Scale bars: G, H $-50 \mu \mathrm{m}$, остальные $-20 \mu \mathrm{m}$.

Рис. 2. Acerentomon brozai sp.n. (G, H - паратип № 1; D-F — паратип № 4; B, С — паратип № 5; остальные - голотип).

A - рострум; В - псевдоокулюс; C - максилярная железа; D - максилярная пальпа; Е и $\mathrm{F}$ - лабиальная пальпа; $\mathrm{G}$ - передняя нога, внешний вид; H - передняя нога, внутренний вид; I — пора psm и сопредельные структуры на тергите VIII; J — вентральная доля тельсона; K - женский генитальный орган; L — мужской генитальный орган. Масштаб: G, H - 50 мкм, остальные - 20 мкм. 
preimago from Givat Wolfson in the collection of Nina Poljakov.

Description. Head setae long. Additional seta absent (Fig. 1A). Rostrum long, LR 4.5-5.5 (Fig. 2A). Pseudoculus abbreviated or nearly round, PR 16.8-19.3 (Fig. 2B).Canal of maxillary gland short, with two indistinct dilations in posterior part, 1.2-2 length of pseudoculus, CF 8.8-14.7 (Fig. 2C). Sensilla of maxillary palp equal, thin, with no basal dilation (Fig. 2D). Sensillum of labial palp leaf-like, slender, dilated basally (Fig. 2E,F).

Setae on nota long (Fig. 1A). Chaetotaxy normal (Table). All accessory setae of normal shape. Seta 1 on pronotum 2-2.5 times longer than seta 2. On mesonotum the length ratio of $P 1: P 1 a: P 2$ as 0.9 $1.0: 1: 1.4-1.6$. Seta $P 5$ on meso- and metanotum as small, conical sensillum evidently longer on mesothan on metanotum. Pronotum with no pores. Mesonotum with $2+2$ pores $(a l$ and $l)$. Metanotum with $1+1$ pore $(l)$.

Seta $A 1$ and $A 2$ on prosternum of equal length. Lateral margin of meso- and metasternum with distinct coxal incision (Fig. 1B,C). Prosternum with no pores. Meso- and metasternum with group of 3-4 pores, situated posterior to seta $A c$.

Foretarsal sensillum $a$ short, reaching base of $d$, slightly thicker than $c ; b$ much thicker than other sensilla, nearly parallel-sided, reaching base of $\beta 5 ; c$ and $e$ equal, shorter than $d, f$ and $g$; sensillum $t 2$ relatively short; $t 3$ large, longer than $t 1$ (Fig. 2G). Sensilla $a$ ' and $c^{\prime}$ 'long (Fig. 2H). Sensilla with exception of $b, t 1$ and $t 3$ thin, parallel-sided. Length formula of sensilla $t 1<t 3<(c=e=t 2)<a<(b=d)<(f=g$ $\left.=a^{\prime}=c^{\prime}\right)$. Claw with no inner teeth. Setas longer than claw. BS 0.5-0.7; TR 3.4-3.9; EU 0.1-0.2.

Chaetotaxy of abdominal segments as on Table. Urotergite VII with no seta $\mathrm{x}$ (Fig. 1D). Accessory setae on urotergite I-VII much shorter than principal ones, of normal shape. Urotergite I with $2+2$ pores (psm and psl), II-VII with $3+3$ pores (psm, psl and $a l$ ). Pleural structures slightly developed - on urotergites II-VI 2-3 small teeth (or granules) close to pore $a l$, on VII no teeth anteriorly to pore and (sometime) some teeth near to it (Fig. 1F).

Abdominal legs with 4, 2, 2 setae. Accessory setae on urosternites I-VII slightly shorter than those on urotergites. Seta $A 1$ on urosternite II mostly absent, on III asymmetrically or absent. Urosternite I-V with single median pore posterior to Ac. Urosternite VI and VII with group of three or four pores situated medially, near anterior margin of sternite, and $2+2$ single pores posterior to seta $A 3$ (Fig. 1E).

Urotergite VIII with one row of strong granules, sometimes with traces of second row (Fig. 1G). Pore psm with 2-3 accompanying teeth (Fig. 2I). Comb VIII composed of $12-15$ teeth (Fig. 1I). Hind margin of laterotergite VIII with 4-7 teeth (Fig. 1J). Urosternite VIII with two rows of strong granules and smooth hind margin (Fig. 1H). Seta $1 a$ absent. Pores absent.

On urotergite IX seta $1 a$ subequal to seta 1 , seta $2 a$ short and thin, seta $3 a$ thick, shorter than half length of seta 3 (Fig. 1G). Urotergite XI with $1+1$ setae (only seta 4 present). Hind margin of urotergite IX-XI smooth. Dorsal lobe of telson with simple median pore, and hind margin smooth. Urosternite IX and X with 4 setae, XI with 6 setae. Ventral lobe of telson with about 10 teeth on hind margin and with $1+1$ anterolateral pores (Fig. 2J). Female squama genitalis with conical acrostyli (Fig. 2K). Penis of normal shape with $4+4$ setae (Fig. $2 \mathrm{~L}$ ).

Chaetal variability (6 imago).

Metasternum - presence of asymmetrical additional seta anteriorly to $P 3(1 \mathrm{sp}-\mathrm{n})$; urosternite II asymmetrical presence of $A 1$ (1 sp-n); urosternite III - symmetrical absence of $A 1$ (2 sp-ns); urosternite VI - presence of $P c$ (1 sp-n); urosternite VII absence of $P c$ (1 sp-n).

Measurements (in $\mu \mathrm{m})$ - imago. Head: 168184, rostrum: $32-39$, pseudoculus: 9-10, maxillary gland: $13-21$, pronotal seta $1: 41-54$, pronotal seta 2: 20-25, mesonotal seta $P 1: 34-45$, P1a: 37-48, $P 2$ : 51-72, foretarsus: $112-118$, claw: $30-35$, empodial appendage: $3-5$, maximum body length about 1770.

Name derivation. The new species is dedicated to our friend, Prof. Dr Meir Broza of the University of Haifa.

Remarks. Acerentomon brozai sp.n. is very similar to $A$. dominiaki and $A$. meridionale. It can be distinguished in very distinct coxal incision on mesoand metasternum (in two other species it is indistinct, nearly absent), and in very poorly developed laterotergal structure. There are only some small teeth on laterotergite $\mathrm{V}$ and VI while in $\mathrm{A}$. dominiaki and $\mathrm{A}$. meridionale there exists distinct row of teeth forming (at last on laterotergite VI) distinct "comb".

The other differences concern the measurement and indexes, and the number of some structures the teeth on the hind margin of laterotergite VIII and the number of teeth of the comb VIII. Those should be checked on the larger material of any studied species.

\section{Acerentomon dominiaki Szeptycki, 1977}

Fig. 3.

Material. Iran, ca $20 \mathrm{~km}$ south of Shahshavar, 22.08. 1972, leg. B. Dominiak, holotype ( + ) and 4 paratypes (3 $9+$, $\left.1 \mathrm{O}^{7}\right)$.

Redescription. Head setae very long (Fig. 3A). Additional seta absent. Rostrum of medium length; LR 5.4-6.1. Pseudoculus nearly round; PR 13.917.6. Canal of maxillary gland short, with two indistinct dilations in posterior part, about two times length of pseudoculus; CF 7.7-10.5. Sensilla of 


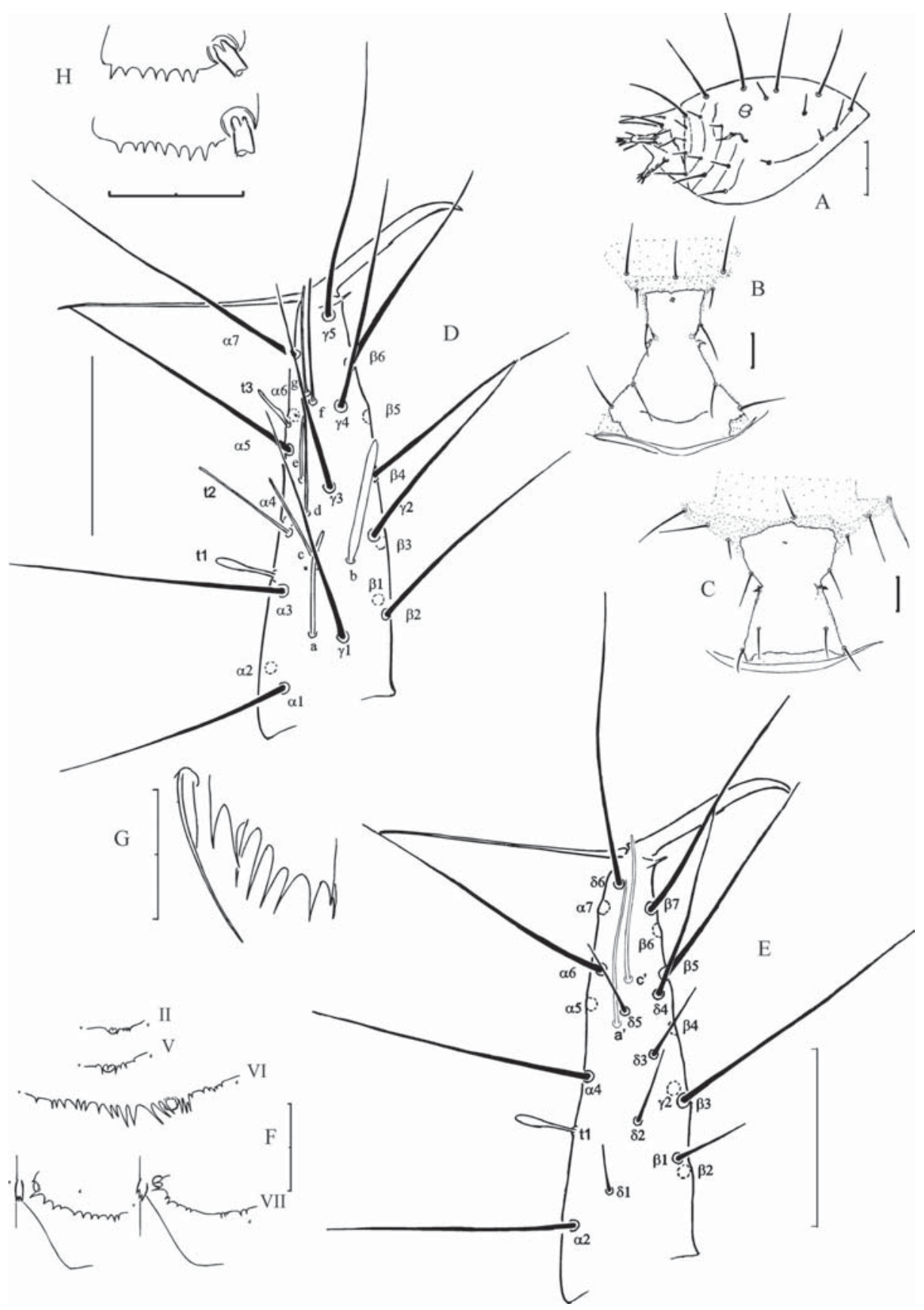

Fig. 3. Acerentomon dominiaki Szeptycki, 1977.

A - head; B - mesosternum; C - metasternum; D - foretarsus, exterior view; E - foretarsus, interior view; F laterotergal structures; $\mathrm{G}$ - comb VIII; H - hind margin of laterotergite VIII. Scale bars: A, D, F - $50 \mu \mathrm{m}$, others $20 \mu \mathrm{m}$.

Рис. 3. Acerentomon dominiaki Szeptycki, 1977.

А - голова; В - мезостернум; C - метастернум; D - передняя нога, внешний вид; Е - передняя нога, внутренний вид; F - структуры латеральной части тергитов; G - комб VIII; H - задний край латеротергита VIII. Масштаб: A, D, F - 50 мкм, остальные - 20 мкм. 
maxillary palp equal, thin, with no basal dilation. Sensillum of labial palp leaf-like, slender, dilated basally.

Setae on nota long. Chaetotaxy normal (Table). All accessory setae of normal shape. Seta 1 on pronotum 3-4 times longer than seta 2. On mesonotum the length ratio of $P 1: P 1 a: P 2$ as $1.1-1.3: 1: 1.4-1.6$. Seta $P 5$ on meso- and metanotum as small, conical sensillum evidently longer on meso- than on metanotum. Pronotum with no pores. Mesonotum with $2+2$ pores $(a l$ and $l$ ). Metanotum with $1+1$ pore $(l)$.

Seta $A 1$ and $A 2$ on prosternum of equal length. Lateral margin of meso- and metasternum with small and indistinct coxal incision (Fig. 3B,C). Prosternum with no pores. Meso- and metasternum with group of 3-4 pores, situated posterior to seta $A c$.

Foretarsal sensillum $a$ short, not reaching base of $d$, slightly thicker than $c ; b$ much thicker than other sensilla, nearly parallel-sided, not reaching base of $\beta 5$; $c$ longer than $e ; d, f$ and $g$ longer than $c$ and $e$; sensillum $t 2$ relatively short; $t 3$ normal, shorter than $t 1 ; a^{\prime}$ and $c^{\prime}$ long (Fig. 3D,E). Sensilla with exception of $b, t 1$ and $t 3$ thin, parallel-sided. Length formula of sensilla $t 3<t 1<e<(c=g=t 2)<(d=f)$ $<(a=b)<\left(a^{\prime}=c^{\prime}\right)$. Claw with small inner tooth. Seta $s$ longer than claw. BS 0.5-0.6; TR 2.6-2.7; EU about 0.1 .

Chaetotaxy of abdominal segments as in A. brozai (Table). Urotergite VII with no seta x. Accessory setae on urotergite I-VII much shorter than principal ones, of normal shape. Urotergite I with $2+2$ pores (psm and psl), II-VII with $3+3$ pores ( $p s m, p s l$ and $a l)$. Pleural structures well developed - on urotergites II-V row of 4-6 distinct teeth close to pore $a l$, on VI "comb" composed of more than 20 irregular, large teeth, on VII no teeth anterior to pore, distinct tubercle ventrally to pore and "comb" composed of about 10 teeth dorsally to it (Fig. 3F).

Abdominal legs with 4, 2, 2 setae. Accessory setae on urosternites I-VII slightly shorter than those on urotergites. Seta $A 1$ on urosternite II mostly present, on III mostly symmetrical (in single specimens asymmetrical or absent). Urosternite I-V with single median pore posterior to $A c$. Urosternite VI and VII with group of three or four pores situated medially, near anterior margin of sternite, and $2+2$ single pores posterior to seta $A 3$.

Urotergite VIII with one row of strong granules (sometimes with traces of second row). Pore psm with 2-4 accompanying teeth. Comb VIII composed of 8-10 teeth (Fig. 3G). Hind margin of laterotergite VIII with 6-8 teeth (Fig. 3H). Urosternite VIII with two rows of strong granules and smooth hind margin. Seta $l a$ absent. Pores absent.

On urotergite IX seta $1 a$ shorter and thinner than seta 1 , seta $2 a$ short and thin, seta $3 a$ thick, shorter than half length of seta 3 . Urotergite XI with $1+1$ setae (only seta 4 present). Hind margin of urotergite IX-XI smooth. Dorsal lobe of telson with simple median pore, and hind margin smooth. Urosternite IX and X with 4 setae, XI with 6 setae. Ventral lobe of telson with about 10 teeth on hind margin and with $1+1$ anterolateral pores. Female squama genitalis with conical acrostyli. Penis of normal shape with 4+4 setae.

Measurements of imago (in $\mu \mathrm{m})$. Head: 174-203, rostrum: 30-35, pseudoculus: $11-13$, maxillary gland: 19-24, pronotal seta $1: 70-83$, pronotal seta $2: 20-24$, mesonotal seta P1: 70-85, P1a: 66-71, P2: 90-103, foretarsus: 126-134, claw: 49-52, empodial appendage: 3-4, maximum body length about 1780 .

Remarks. The drawing of the exterior side of foretarsus of the original description (Szeptycki, 1977, fig. 21) is partly false - sensilla $a$ and $c$ are too long. Sensillum $b$ is relatively longer, too - but it is not a mistake, but rather results of the variability of the length of it.

\section{Acerentomon meridionale Nosek, 1960}

Fig. 4.

Material. Slovenia, Julian Alps, Mt Orla Glava; 15. 05. 1974, 1 †, leg. K. Bartkowska.

Redescription. Head setae very long (Fig. 4A). Additional seta absent. Rostrum relatively short; LR about 8 . Pseudoculus nearly round, small; PR about 21 (Fig. 4B). Canal of maxillary gland short, with two indistinct dilations in posterior part, about two times length of pseudoculus; CF about 11 (Fig. 4C). Sensilla of maxillary palp equal, thin, with no basal dilation. Sensillum of labial palp leaf-like, slender, dilated basally.

Setae on nota long. Chaetotaxy normal (Table). All accessory setae of normal shape. Seta 1 on pronotum about 4 times longer than seta 2 . On mesonotum the length ratio of $P 1: P 1 a: P 2$ as 1.1 : 1 : 1.3-1.4. Seta $P 5$ on meso- and metanotum as small, conical sensillum evidently longer on mesothan on metanotum. Pronotum with no pores. Mesonotum with $2+2$ pores $(a l$ and $l$ ). Metanotum with $1+1$ pore $(l)$.

Seta $A 1$ and $A 2$ on prosternum of equal length. Lateral margin of meso- and metasternum with small and indistinct coxal incisions (Fig. 4D,E). Prosternum with no pores. Meso- and metasternum with group of 2-3 pores, situated posterior to seta $A c$.

Foretarsal sensillum $a$ long, reaching base of $e$, thicker than $c ; b$ much thicker than other sensilla, nearly parallel-sided, reaching base of $\beta 5 ; c$ and $e$ long, subequal in length to $d ; f$ and $g$ short; $t 2$ relatively short; $t 3$ normal; $a$ ' and $c$ ' long (Fig. $4 \mathrm{~F}, \mathrm{G})$. Sensilla with exception of $b$ and $t 3$ thin, parallel-sided. Length formula of sensilla $t 3<(f=\mathrm{g}$ $=t 2)<b<(a=c=d=e)<c^{\prime}<a^{\prime}$. Claw with very 


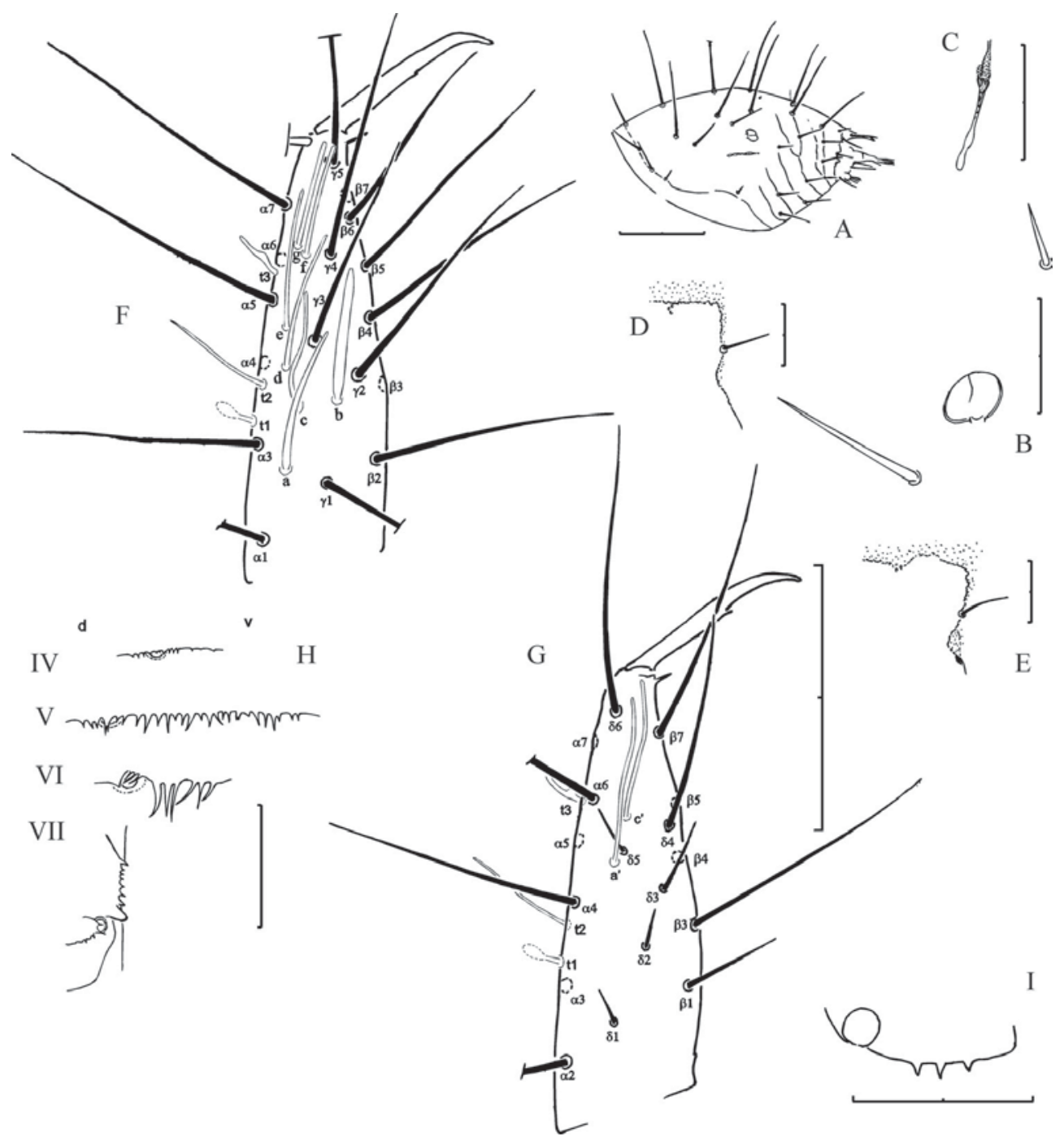

Fig. 4. Acerentomon meridionale Nosek, 1960.

A — head; B - pseudoculus; C - maxillary gland; D — anterior part of mesosternum; E — anterior part of metasternum; $\mathrm{F}$ - foretarsus, exterior view; $\mathrm{G}$ - foretarsus, interior view; $\mathrm{H}$ - laterotergal structures; $\mathrm{I}$ - hind margin of laterotergite VIII. Scale bars: A, D-G $-50 \mu \mathrm{m}$, others $-20 \mu \mathrm{m}$.

Рис. 4. Acerentomon meridionale Nosek, 1960.

А — голова; В — псевдоокулюс; C - максилярная железа; D - передняя часть мезостернума; Е — передняя часть метастернума; F - передняя нога, внешний вид; $\mathrm{G}$ - передняя нога, внутренний вид; H - структуры латеральной части тергитов; I — задний край латеротергита VIII. Масштаб: A, D-G - 50 мкм, остальные - 20 мкм.

indistinct inner tooth (sensillum $t 1$ and seta $\mathrm{s}$ are broken off in mine specimens). BS about 0.6; TR 2.5; EU about 0.1 .

Chaetotaxy of abdominal segments as in A. brozai (Table). Urotergite VII with no setax. Accessory setae on urotergite I-VII much shorter than principal ones, of normal shape. Urotergite I with $1+1$ pores (psm, pore psl is lacking), II-VII with $3+3$ pores (psm, psl and $a l$ ). Pleural structures strongly developed - on laterotergites III-IV row of 6-10 very small teeth close to pore al, on V very long "comb" composed of about 30 more or less regular teeth, on 
VI group of about 9 large teeth, on VII row of about 7 teeth anteriorly to pore, large tubercle ventrally to pore, and some smaller teeth close to it (Fig. 4H).

Abdominal legs with 4, 2, 2 setae. Accessory setae on urosternites I-VII slightly shorter than those on urotergites. Seta $A 1$ on urosternite II, III and IV absent. Urosternite I-V with single median pore posterior to $A c$. Urosternite VI and VII with group of three or four pores situated medially, near anterior margin of sternite, and $2+2$ single pores posterior to seta $A 3$.

Urotergite VIII with one row of strong granules. Pore psm with 2-3 surrounding teeth. Comb VIII composed of 13 teeth. Hind margin of laterotergite VIII with 3 teeth (Fig. 4I). Urosternite VIII with two rows of strong granules and smooth hind margin. Seta $1 a$ absent. Pores absent.

On urotergite IX seta $1 a$ subequal to seta $1, \operatorname{seta} 2 a$ short and thin, and seta $3 a$ thick, shorter than half length of seta 3 . Urotergite XI with $1+1$ setae (only seta 4 present). Hind margin of urotergite IX-XI smooth. Dorsal lobe of telson with simple median pore, and hind margin smooth. Urosternite IX and X with 4 setae, XI with 6 setae. Ventral lobe of telson with 9 teeth on hind margin and with $1+1$ anterolateral pores. Female squama genitalis with conical acrostyli.

Measurements (in ?m) — imago. Head: 110, rostrum: 22, pseudoculus: 9, maxillary gland: 17 , pronotal seta $1: 65$, pronotal seta $2: 17$, mesonotal seta $P 1$ : 66, P1a: 58, P2: 82, foretarsus: 109, claw: 45, empodial appendage: 4, body length about 1560 .

Remarks. A. meridionale was described by Nosek (1960), and redescribed by Tuxen (1964) and Nosek (1973). The differences between mentioned description and that presented here concern some proportion (LR and PR) and the number of setae on urotergite XI.

In the original description LR is given as 5.05.3; but Tuxen calculated it as 6-7. In the monograph of Nosek it is 6. The index PR is recorded in all quoted papers as 16 . There are no data about the variability of mentioned indexes. All measurements of the head and details of it are very difficult to be taking precisely - so we don't think that the differences between indexes from the older publication and that given here are taxonomically important.

In the original description the number of setae on urotergite XI is given as two, but in the later redescriptions it is 4 . We suppose that it is result of the mistake of Tuxen - the setae on XI tergite are very difficult to observe.

\section{Acknowledgements}

We are very grateful to Prof. Dr Meir Broza and Mrs Dina Poljakov for the sending us very interesting material of Protura from Israel, and to Mrs Dina Poljakov for her help during the preparing of the manuscript. The financial support of the Mianowski Found and the Director of the Institute of Systematics and Evolution of Animals, Polish Academy of Sciences make our collaboration possible.

\section{Literature}

Broza M., Poliakov D., Szeptycki A. 1996. First record of Protura (Hexapoda) in Israel with notes on their distribution and ecology // Israel Journal of Entomology. Vol.30. P.1-5.

Nosek J. 1960. Sur une nouvelle espéce de Protoures Acerentomon meridionale sp. $\mathrm{n}$. // Zoologické Listy. No.9. P.7-10.

Nosek J. 1973. The European Protura. Their taxonomy, ecology and distribution. With keys for determination. Geneve: Mus. hist. nat. 345 p.

Szeptycki A. 1977. Three new species of Protura from Iran // Polskie Pismo entomologiczne. T. 47. P. 691-701.

Tuxen S.L. 1964. The Protura. A revision of the species of the world. With keys for determination. Paris: Hermann. 360 p. 